\title{
Problematika Putus Sekolah Dan Pengangguran (Analisis Sosial Pendidikan )
}

\author{
Muh. Dahlan Thalib \\ Sekolah Tinggi Agama Islam Negeri
}

\begin{abstract}
Abstrac
Leaving school and joblessness were the problematic social reality in education. The factors of dropping out today are endogenous (self) and exogenous (environmental) factors. This paper tries to describe the social education. This is due to the lack of religious social upbringing, lack of parents' understanding of education in economic and social conditions, and cultural, social environment and low IQ factors. While the problem of unemployment is more dominant due to professionalism or educational skills that are oriented to the fulfillment of the world of work.

Alternative solutions to solving the problem of leaving school include: (a) equitable distribution of the educational social environment; (b) promote the concept of lifelong education; (c) the use of various work activities for school dropouts and unemployment; (d) maximizing the role of the family's social environment in the continuation of children's education; (e) implement free education policy efforts. The availability of educational institutions that are equitable with the support of adequate facilities, then supported by the atmosphere of a social environment that is oriented to improving the quality of education that is sustainable will be able to develop an educational orientation based on work professionalism.
\end{abstract}

\section{Keywords: Leaving School, Social Education}

\begin{abstract}
Abstrak
Putus sekolah dan pengangguran merupakan problematika realitas sosial dalam dalam dunia pendidikan. Faktor-faktor terjadinya putus sekolah dewasa ini adalah faktor endogen (diri sendiri) dan faktor eksogen (lingkungan). Tulisan ini mencoba mendeskripsikan secara sosial pendidikan. Hal ini diakibatkan kurangnya didikan sosial keagamaan, kurangnya pengertian orang tua tentang pendidikan keadaan ekonomi dan sosial, dan faktor budaya, lingkungan sosial dan IQ yang rendah. Sedangkan masalah pengangguran lebih dominan diakibatkan oleh faktor profesionalisme atau keterampilan pendidikan yang berorientasi pada pemenuhan dunia kerja.

Solusi alternatif pemecahan masalah putus sekolah, antara lain: (a) pemerataan lingkungan sosial pendidikan; (b) menggalakkan konsep
\end{abstract}


pendidikan seumur hidup; (c) pemaanfaatan berbagai kegiatan kerja bagi putus sekolah dan pengangguran; (d) memaksimalkan peran lingkungan sosial keluarga dalam kelanjutan pendidikan anak; (e) melaksanakan upaya kebijakan pendidikan gratis. Ketersediaan lembaga pendidikan yang merata dengan dukungan fasilitas yang memadai, kemudian ditunjang oleh suasana lingkungan sosial masyarakat yang berorientasi pada peningkatan mutu pendidikan yang berkelanjutan akan mampu mengembangkan orientasi pendidikan yang berbasis profesinalisme kerja.

\section{PENDAHULUAN}

\section{A. Latar Belakang}

Anak-anak diarahkan untuk bersekolah di berbagai lembaga pendidikan, karena pendidikan adalah suatu kebutuhan pokok, ia setara dengan kebutuhan manusia terhadap pangan dan sandang. Dewasa ini, ternyata masih ada sebagian masyarakat yang tidak mampu menyelesaikan pendidikan di berbagai tingkatan, jenis dan struktur lembaga pendidikan dengan berbagai alasan. Mereka akhirnya putus sekolah yang antara lain alasannya adalah faktor dana dan pembiayaan. Sekarang ini, pemerintah Repulik Indonesia, khususnya dalam lingkup Pemerintahan Daerah telah beramai-ramai mencanangkan pendidikan gratis sekolah untuk mengantisipasi banyaknya masyarakat putus sekolah, utamanya karena faktor dana dan alasan biaya yang tidak mencukupi.

Sebagai akibat dari putus sekolah, terutama bagi mereka dalam usia remaja memiliki dampak pengaruh di tengah-tengah masyarakat, tentu saja harus segera diantisipasi. Untuk mengetahui hal tersebut, maka diperlukan kajian lebih lanjut tentang sejumlah indikator akibat terjadinya putus sekolah yang berimplikasi munculnya pengangguran. Berbagai upaya yang telah dilakukan untuk mengantisipasi kedua penomena sosial dalam lingkup masyarakat sekarang ini, namun ironisnya ternyata sejumlah indikator yang ada belum sepenuhnya memenuhi perubahan sosial pendidikan, baik dalam lingkup strukturalisasi pendidikan maupun dalam lingkup kulturasi sosial-budaya secara umum.

Secara nasional, tujuan pendidikan diletakkan pada tiga pilar, yaitu (1) pemerataan kesempatan dan perluasan akses; (2) peningkatan mutu, relevansi, dan daya saing; (3) penguatan tata kelola, akuntabilitas, dan pencitraan publik. Pilar Pemeratan kesempatan dan perluasan akses merupakan salah satu upaya meningkatkan kualitas sumber daya manusia melalui penciptaan dan peningkatan layanan pendidikan kepada seluruh warga negara. Pemerintah mencanangkan program Wajib Belajar Pendidikan Dasar 9 Tahun yang bermutu dan tuntas pada tahun 2008. Namun sebuah fakta muncul kemudian, bahwa gerakan Wajib Belajar 9 Tahun justru menenggelamkan nilai-nilai pendidikan yang sebenarnya diakibatkan oleh berbagai penyimpangan dalam peningkatan dan penggunaan anggaran pendidikan dasar. Bahkan program 
Wajar 9 Tahun hanya dijadikan sebagai akses penguatan informasi publik yang syarat dengan berbagai kepentingan untuk memegang kendali pemerintahan.

Kondisi serupa semakin diperparah oleh kondisi sosial pendidikan pada jenjang pendidikan selanjutnya, yakni pada tingkat SMA/SMU hingga di Perguruan Tinggi, justru semakin mengalami masalah besar seiring dengan semakin melebarnya akses pendidikan, utamanya dalam memasuki ambang pintu dunia kerja. Relevansi antara kondisi sosial pendidikan akibat putus sekolah dengan maraknya pengangguran merupakan realitas yang tidak terbantahkan lagi. Putus sekolah yang berakibat lahirnya penganggurang memiliki pengaruh signifikan dalam membentuk citra, watak dan martabat kehidupan harmonis dalam berkebangsaan, berperadaban dan berkeagamaan. Olehnya itu, capaian tujuan sosial pendidikan yang diharapkan adalah menata kondisi ranah sosial-budaya masyarakat dan dipahami sebagai bagian integral dari nilai-nilai universal dari tujuan pendidikan. Makalah ini akan melirik sebuah realitas sosial masyarakat dalam dimensi pendidikan dengan menfokuskan pada capaian tujuan pendikan secara simultan dan paripurna.

\section{B. Rumusan Masalah}

Relevan dengan uraian yang telah dikemukakan di atas, maka masalah pokok yang akan dijadikan subjek kajian, sebagai berikut:

1. Apa indikator yang mempengaruhi terjadinya putus sekolah dan pengangguran?

2. Bagaimana pengaruh putus sekolah dan pengangguran terhadap kondisi sosial remaja dan impilikasinya bagi kondisi sosial masyarakat?

3. Bagaimana alternatif pemecahan masalah dalam mengantisipasi terjadinya putus sekolah dan penganggurang?

\section{PEMBAHASAN}

\section{A. Pengertian Konsep}

Secara kebahasaan putus sekolah ${ }^{1}$ mengandung arti tidak adanya hubungan lagi dengan sekolah. Sebagaimana dalam definisi yang dikemukakan Moh. Shohib, bahwa :

Putus sekolah adalah keadaan tidak melanjutkan pendidikan pada lembaga pendidikan formal, baik karena dikeluarkan dari sekolah, atau karena tidak melanjutkan pendidikan ke jenjang pendidikan formal berikutnya yang lebih tinggi dengan berbagai alasan. ${ }^{2}$

${ }^{1}$ Secara etimologi, putus artinya, tidak berhubungan, rampung, berakhir, hilang tidak adalagi kaitan. Departemen Pendidikan Nasional RI, Kamus Besar Besar Bahasa Indonesia (Cet.IX; Jakarta: Balai Pustaka, 1997), h. 914. Sedangkan sekolah adalah lembaga pendidikan formal misalnya SD sederajat, SMP sederajat atau SMU sederaja.

${ }^{2}$ Moh. Shohib, Pola Asuh Orang Tua (Cet. I; Jakarta: PT. Rineka Cipta, 1998), h. 18 
Berdasar pada batasan definisi di atas, maka pengertian putus sekolah dapat dilihat dalam dua segi. Pertama, tidak melanjutkan pedidikan secara formal di suatu sekolah karena alasan dikeluarkan atau alasan lain. Kedua, tidak melanjutkan pendidikan formal yang lebih tinggi, misalnya dari tamatan SD tidak lanjut ke SMP, atau dari SMP ke SMA karena berbagai alasan atau faktor yang menyebabkannya.

Di negara berkembang seperti Indonesia, persoalan putus sekolah menjadi suatu problematika tersendiri, dan menyebabkan sebagian besar penduduk dalam keadaan buta huruf dan pendidikan yang tidak berlanjut. Cara yang paling efektif untuk keluar dari lingkaran kemelaratan dan kebodohan adalah melalui pendidikan sosial kemasyarakatan, orang tua sebagai penanggung jawab keluarga harus menyadari betapa pentingnya bagi anak untuk mengenyam pendidikan, bila tidak, maka anak kurang mendapat pendidikan sekolah, putus sekolah atau bahkan tidak pernah sama sekali mendapat pendidikan dibangku sekolah. Sementara satu sisi pengelola pendidikan, utamanya penanggungjawab pendidikan harus memiliki fungsi ganda untuk menyikapi kemungkinan terjadinya putus sekolah bagi peserta didiknya.

Masalah kependidikan yang serius dihadapi pada umumnya, antara lain berkisar pada masalah mutu pendidikan, kesiapan tenaga pendidik, fasilitas, dan lapangan pekerjaan. Masalah yang terakhir memiliki cakupan yang sangat kompleks sebagai bagian nilai sosial yang berimplikasi dari sebuah proses pendidikan. Kekurangtersediaan lapangan pekerjaan akan berimbas pada kemapanan sosial dan eksistensi pendidikan dalam perspektif masyarakat. Dalam kerangka ini, dipahami bahwa pendidikan harus diposisikan sebagai sarana untuk peningkatan kesejahteraan melalui pemanfatan kesempatan kerja yang ada. Sedangkan tujuan akhir program pendidikan bagi masyarakat pengguna jasa pendidikan, adalah teraihnya lapangan kerja yang diharapkan.

Tidak ditemukan literatur yang pasti mengenai terminologi pengangguran. Namun dalam pengertian secara publik, pengangguran adalah orang yang masuk dalam angkatan kerja (berkisar 15 - 64 tahun) yang sedang mencari dan/atau belum mendapatkan pekerjaan. Orang yang tidak/sedang mencari kerja, seperti ibu rumah tangga, siswa sekolan SMP, SMA, Mahasiswa PT, dan sebagainya, tidak/belum dikategorikan membutuhkan pekerjaan.

Sesederhana apapun pengertian tentang arti penganguran, namun yang sangat penting dan aktual disikapi dalam realitas sosial masyarakat adalah terkait dengan jenis atau macam pengangguran. Dimas Apriyana mengemukakan bahwa pengangguran terdiri dari komponen, sebagai berikut: ${ }^{3}$

1. Pengangguran Friksional (Frictional Unemployment). yakni pengangguran yang sifatnya sementara yang disebabkan adanya kendala waktu, informasi

\footnotetext{
${ }^{3}$ Lihat: http://dimas-apriyana.blogspot.com/.html.
} 
dan kondisi geografis antara pelamar kerja dengan pembuka lamaran pekerjaan.

2. Pengangguran Struktural (Structural Unemployment), yakni keadaan di mana penganggur yang mencari lapangan pekerjaan tidak mampu memenuhi persyaratan yang ditentukan pembuka lapangan kerja. Semakin maju suatu perekonomian suatu daerah akan meningkatkan kebutuhan akan sumber daya manusia yang memiliki kualitas yang lebih baik dari sebelumnya.

3. Pengangguran Musiman (Seasonal Unemployment), yakni keadaan menganggur karena adanya fluktuasi kegiaan ekonomi jangka pendek yang menyebabkan seseorang harus nganggur. Contohnya petani yang menanti musim tanam, tukang jualan jagung atau durian yang menanti datangnya musim jagung atau durian.

4. Pengangguran Siklikal, yakni pengangguran yang menganggur akibat imbas naik turun siklus ekonomi sehingga permintaan tenaga kerja lebih rendah daripada penawaran kerja.

Terdapat pula jenis pengangguran dalam perpektif lain, yakni pengangguran sukarela (voluntary unemployment) dan dukalara (involuntary unemployment). Pengangguran suka rela adalah pengangguran yang menganggur untuk sementara waktu karena ingin mencari pekerjaan lain yang lebih baik. Sedangkan pengangguran duka lara adalah pengangguran yang menganggur karena sudah berusaha mencari pekerjaan namun belum berhasil mendapatkan kerja. ${ }^{4}$ Penulis berpendapat bahwa kedua jenis pengangguran ini dikategorikan sebagai pengangguran disebabkan oleh psiko-sosial dalam pendidikan.

Sesungguhnya, relevansi antara dunia pendidikan setelah melalui proses pendidikan dan dinyatakan lulus, kemudian dapat bekerja di sektor formal, memiliki nilai sosial kejiwaan (psiko-sosial) yang lebih tinggi di banding sektor informal. Keterbatasan lapangan pekerjaan yang berpotensi untuk tidak dapat tertampungnya lulusan program pendidikan di lapangan kerja, secara linear berpotensi menggugat eksistensi dan urgensi pendidikan dalam perspektif masyarakat. Masyarakat akan kehilangan kepercayaan secara signifikan terhadap eksistensi lembaga pendidikan. Lapangan pekerjaan merupakan indikator penting tingkat kesejahteraan masyarakat dan sekaligus menjadi indikator keberhasilan penyelenggaraan pendidikan.

\section{B. Faktor-faktor dan Pengaruh terjadinya Putus Sekolah dan Pengangguran}

\footnotetext{
${ }^{4}$ Ibid.
} 
Meskipun pencanangan wajib belajar pendidikan dasar 9 tahun oleh pemerintah sejak tahun $1994,{ }^{5}$ menunjukkan keberhasilan jika dilihat dari angka partisipasi sekolah di semua tingkatan. Angka partisipasi murni SD saat ini sudah mencapai 90 persen lebih, sedangkan SMP di angka 60-an persen dengan tren membaik setiap tahun. Namun, keterbatasan kemampuan sebagian masyarakat mengelola pendidikan tampak dari masih relatif tingginya angka putus sekolah. Di tingkat pendidikan dasar, putus sekolah masih menjadi perhatian serius dalam upaya penuntasan wajib belajar. Angka putus sekolah seluruh jenjang pendidikan di Indonesia empat tahun terakhir masih di atas satu juta siswa per tahun. Dari jumlah itu, sebagian besar ( 80 persen) adalah mereka yang masih duduk di jenjang pendidikan dasar (SD-SMP). ${ }^{6}$

Pada kenyataannya, kemajuan dan dunia globalisasi telah banyak mempengaruhi putus sekolah, terjadinya penyalagunaan narkoba atau sejenisnya, pergaulan bebas pria dan wanita, kriminalitas, dan lain-lain. ${ }^{7}$ Fenomena perilaku negatif lain yang terjadi pada generasi muda akibat putus sekolah adalah terjadinya pengangguran, boleh jadi menggiring diri mereka pada perilaku kriminalitas dan norma-norma etika agama. Bahkan menurut laporan dari United Nation Congres of The Prevention of Crime yang melakukan pertemuan di London pada tahun 1990-an bahwa adanya kenaikan signifikan jumlah putus sekolah. ${ }^{8}$ Fakta ini kemudian menunjukkan bahwa semua tipe kejahatan bagi mereka yang putus sekolah semakin meningkat seiring dengan semakin lajunya perkembangan industrialisasi dan urbanisasi.

Putus sekolah yang terjadi pada sebagian masyarakat dewasa ini, adalah faktor endogen (diri sendiri) dan faktor eksogen (lingkungan). Faktorfaktor tersebut disebabkan oleh beberapa alasan dan keadaan yaitu sebagai berikut :

Pertama, kualitas diri bagi yang bersangkutan itu sendiri, seperti perkembangan emosional yang kurang bahkan tidak sehat, mengalami

${ }^{5}$ Kemudian Presiden mengeluarkan Instruksi No. 5 Tahun 2006 tentang Gerakan Percepatan Penuntasan Wajib Belajar 9 Tahun, namun target ketuntasan nya sebagaimana yang diharapkan empat tahun terakhir belum mencapai hasil yang significant.

6 Selengkapnya lihat http://www.menegpp.go.id/index.php?option=com,- putus sekolah menjadi masalah. Dari data yang diakses ini ternyata dilihat secara persentase, jumlah total siswa yang putus sekolah dari SD atau SMP memang hanya berkisar 2 hingga 3 persen dari total jumlah siswa. Namun, persentase yang kecil tersebut menjadi besar jika dilihat angka sebenarnya. Jumlah anak putus sekolah SD setiap tahun rata-rata berjumlah 600.000 hingga 700.000 siswa. Sementara itu, jumlah mereka yang tidak menyelesaikan sekolahnya di SMP sekitar 150.000 sampai 200.000 orang. 1998), h. 46.

${ }^{7}$ Lihat, Moekti Ali, Generasi Muda Islam (Cet.II; Bandung: Remaja Rosdakarya,

${ }^{8}$ Kartini Kartono, Patalogi Sosial 2 Kenakalan Remaja (Cet II; Jakarta : Rajawali, 1992), h. 3. 
hambatan dalam perkembangan hati nurani yang bersih dan agamis, ketidak mampuan mempergunakan waktu luang secara tidak sehat dan ekonomis.

Kedua, kualitas ekonomi yang rendah dan lingkungan keluarga dalam keadaan pra sejahtera. Dalam hal keadaan ekonomi yang tidak mendukung kemauan dan kesempatan belajar mengakibatkan mereka putus sekolah. ${ }^{9}$

Sementara faktor lain yang secara ringkas disebutkan dapat menyebabkan putus sekolah adalah : (1) Faktor kurangnya pembinaan dan bimbingan orang tua, (2) Faktor ekonomi atau kemiskinan, (3) Faktor demoralisasi seksual dan demoralisasi akibat dari perubahan dan globalisasi, (4) Faktor keinginan yang tidak terkendali, dan (5) Pengaruh alkohol dan kebiadaban. ${ }^{10}$ Demikian pula faktor kultur budaya masyarakat peternalistik.

Indikator lain menyebabkan terjadinya putus sekolah secara fisik dan fisikis yang berakibat pada dekadensi moral khususnya kepada generasi muda, dapat diidentifikasi, antara lain: (1) Ekonomi yang tidak mapan; (2) Meningkatnya agresivitas dan dorongan seksualnya; (3) Salah asuh dan salah didik orang tua, sehingga anak jadi manja dan bermental lemah; (4) Hasrat untuk berkumpul, hura-hura dan kesukaan untuk meniru-niru perilaku orang lain; (5) Kecenderungan pembawaan yang patologis atau abnormal; dan (6) Konflik batin sendiri, kemudian menggunakan cara-cara pelarian diri dan pembelaan diri yang irasional. ${ }^{11}$

Sesungguhnya masih banyak faktor dan sebab-sebab yang dapat menyebabkan putus sekolah, dan timbulnya dekadensi moral, antara lain disebabkan oleh faktor ekonomi sebagaimana yang berkali-kali disebutkan, lingkungan keluarga, ekonomi, sosial, budaya, lingkungan pergaulan dan lainlain. Selain perilaku-peerilaku yang tidak baik yang didapatkan dari orang dewasa seperti film, komik yang bersifat porno dan tidak mengindahkan nilainilai dan mutu tetapi hanya mementingkan segi komersial semata-mata. ${ }^{12}$ Searah dengan terma ini maka dapat dirumuskan, sebagai berikut: ${ }^{13}$

1. Kurangnya didikan sosial keagamaan.

Didikan agama bukan hanya sebatas pengajaran agama yang diberikan secara sengaja dan teratur seperti yang dilakukan oleh guru di sekolah, namun yang lebih penting adalah penanaman jiwa agama yang dimulai di rumah tangga sejak kecil dengan cara pembiasaan, latihan dan pengalamanpengalaman. Kebiasaan-kebiasaan yang baik itu sesuai dengan pendidikan

\footnotetext{
${ }^{9}$ Yudha Purwoko, Memecahkan Masalah Remaja (Cet I; Bandung: Nuansa, 2001), h.

15.

${ }^{10}$ Lihat, Ibid., h. 22.

${ }^{11}$ Lihat, Ibid.

${ }^{12}$ Lihat H. A. Rahman Getteng, Pendidikan Islam dalam Pembangunan (Ujung Pandang : Yayasan al-Ahkam, 1997), h. 55.

${ }^{13}$ Rumusan yang dikemukakan disadur dari Yudha Purwoko, op. cit., h. 24-30.
} 
agama, yaitu lebih mudah tertanam pada jiwa anak, apabila orang dewasa dalam lingkungan rumah tangga terutama kedua orang tua memberi contoh teladan yang baik dalam kehidupan.

2. Kurang pengertian orang tua tentang pendidikan

Memberikan pendidikan pada anak mengalami kesulitan disebabkan karena masih banyaknya orang tua yang belum mengerti tentang bagaimana sebenarnya menanamkan pendidiakn agama terhadap anaknya, mereka beranggapan bahwa apabila sudah memenuhi kebutuhan makan, pakaian cukup sesuai dengan kebutuhan selesailah tugas mereka, tidak memperdulikan pendidikan padahal pendidikan merupakan suatu usaha atau perbaikan bagi orang yang bertanggung jawab terhadap anak-anak yang sedang mengalami pertumbuhan budi pekerti, akhlak yang baik, intelek serta jasmaninya menuju kepada kedewasaan dan bertanggung jawab.

M. Ngalim Purwanto mengemukakan bahwa berhasil baik atau tidaknya pendidikan di sekolah bergantung pada dan dipengaruhi oleh pendidikan di dalam keluarga. Pendidikan keluarga adalah fundamen atau dasar dari pendidikan anak selanjutnya. Hasil-hasil pendidikan yang diperoleh anak dalam keluarga menentukan pendidikan anak itu selanjutnya, baik di sekolah maupun di masyarakat. ${ }^{14}$ Pandangan tersebut di atas menunjukkan betapa perlunya orang tua senantiasa memperhatikan perkembangan dan kemajuan pendidikan anak-anaknya, sebab perhatian dan bimbingan yang cukup dari orang tua sangat menunjang bagi keberhasilan pendidikan anak.

Dalam lingkungan keluarga yang terpenting bagi anak adalah keseluruhan perlakuan-perlakuan orang tua terhadap putera-puteranya yang diterima dalam lingkungan keluarga, mereka merasa disayangi dan diperhatikan oleh kedua orang tuanya. Bahkan anak membutuhkan kasih sayang tertentu jika orang mengalami kekurangan kasih sayang maka perkembangan anak menjadi tidak baik. Bila mana anak merasa tidak disayangi dan kurang mendapat perhatian dari orang tuanya maka ia mencari jalan lain yang bermacam-macam cara yang ditempuhnya misalnya melaksanakan kelakuan-kelakuan yang menarik perhatian, tidak mau mengindahkan apa-apa yang disampaikan akibat perasaan yang tertekan maka makin menjadi-jadi kelakuannya.

3. Faktor keadaan Ekonomi dan Sosial

Apabila keadaan ekonomi tidak stabil dan stabiltas sosial tidak terjaga, maka masyarakat akan mengalami kegoncangan dan kegelisahan disebabkan karena perubahan yang menimbulkan kegoncangan. Hal ini timbul di masyarakat dan bisa berbias pada terjadinya putus sekolah, dan pengangguran yang merajalela.

\footnotetext{
${ }^{14}$ M. Ngalim Purwanto, Ilmu Pendidikan Teoritis dan Praktis (Cet. XV; Bandung: Remaja Rosdakarya, 2003), h. 79.
} 
Dari uraian di atas, maka dapat dipahami bahwa yang menyebabkan terjadinya putus sekolah, banyak alasan dan faktor-faktor yang melatarbelakanginya. Hal tersebut bisa terjadi karena adanya faktor interen, tetapi juga banyak faktor lain diluar dari diri (eksteren) yang dapat mempengaruhinya. Olehnya karena itu, perlu orang tua, keluarga, masyarakat dan pemerintah bersama-sama mengantisipasi hal-hal yang dapat menyebabkan terjadinya putus sekolah, dan di antara upaya itu adalah memasyaratkan pendidikan seumur hidup. Hubungannya dengan sosialisasi remaja atau generasi muda khususnya yang mengalami putus sekolah, mengalami problematika tersendiri baik secara internal dan eksternal bagi diri mereka.

4. Faktor budaya, lingkungan sosial dan IQ yang rendah

Faktor budaya yang dimaksudkan di sini adalah terkait dengan kebiasaan masyarakat di sekitarnya. Hal ini lebih dominan terjadi di lingkungan pedesaan, yaitu rendahnya kesadaran orang tua atau masyarakat akan pentingnya pendidikan. Perilaku masyarakat pedesaan dalam menyekolahkan anaknya lebih banyak dipengaruhi faktor lingkungan. Mereka beranggapan tanpa bersekolah pun anak-anak mereka dapat hidup layak seperti anak lainnya yang bersekolah. Oleh karena di desa jumlah anak yang tidak bersekolah lebih banyak dan mereka dapat hidup layak maka kondisi seperti itu dijadikan landasan dalam menentukan masa depan anaknya. Sementara faktor lainnya adalah cacat, IQ yang rendah, rendah diri, dan umur yang melampaui usia sekolah. Faktor ini akibat akses informasi pendidikan yang lambat dan dapat diterima dalam lingkup sosial masyarakat yang paternalistik.

Sedangkan masalah pengangguran lebih dominan diakibatkan oleh faktor profesionalisme atau keterampilan pendidikan yang berorientasi pada pemenuhan dunia kerja. Masalah ketenagakerjaan sekarang ini sudah mencapai kondisi yang cukup memprihatinkan ditandai dengan jumlah penganggur yang besar, pendapatan yang relatif rendah dan kurang merata. Sebaliknya pengangguran yang tinggi merupakan pemborosan pemborosan sumber daya dan potensi yang ada, menjadi beban keluarga dan masyarakat, sumber utama kemiskinan, dapat mendorong peningkatan keresahan sosial dan kriminal, dan dapat menghambat pembangunan dalam jangka panjang.

Pengangguran terjadi disebabkan antara lain, yaitu karena jumlah lapangan kerja yang tersedia lebih kecil dari jumlah pencari kerja, kompetensi pencari kerja tidak sesuai dengan pasar kerja. Selain itu juga kurang efektifnya informasi pasar kerja bagi para pencari kerja. Tingginya angka pengangguran, masalah ledakan penduduk, distribusi pendapatan yang tidak merata, dan berbagai permasalahan lainnya menjadi salah satu faktor utama rendahnya taraf hidup para penduduk.

Pengangguran umumnya disebabkan karena jumlah angkatan kerja tidak sebanding dengan jumlah lapangan pekerjaan yang mampu menyerapnya. Pengangguran seringkali menjadi masalah dalam perekonomian karena dengan 
adanya pengangguran, produktivitas dan pendapatan masyarakat akan berkurang sehingga dapat menyebabkan timbulnya kemiskinan dan masalah sosial lainnya. Tidak adanya pendapatan menyebabkan penganggur harus mengurangi pengeluaran konsumsinya yang menyebabkan menurunnya tingkat kemakmuran dan kesejahteraan. Pengangguran yang berkepanjangan juga dapat menimbulkan efek psikologis yang buruk terhadap penganggur dan keluarganya.

Hal ini terjadi karena pengganguran berdampak negatif terhadap kegiatan perekonomian, seperti yang dijelaskan di bawah ini: pertama, Pengangguran bisa menyebabkan masyarakat tidak dapat memaksimalkan tingkat kemakmuran yang dicapainya. Kedua, Pengangguran akan menyebabkan pendapatan nasional yang berasal dari sektor pajak berkurang. Ketiga, Pengangguran tidak menggalakkan pertumbuhan ekonomi. Adanya pengangguran akan menyebabkan daya beli masyarakat akan berkurang sehingga permintaan terhadap barang-barang hasil produksi akan berkurang.

\section{Solusi Alternatif pemecahan Masalah Putus Sekolah dan Pengangguran.}

Beberapa langkah strategis dalam pemecahan masalah putus Sekolah dan Pengangguran, sebagai berikut:

1. Pemerataan Lingkungan Sosial Pendidikan

Secara universal data dan indikator pendidikan tertumpu pada tiga aspek penting, yaitu: (1) Pemerataan kesempatan dan perluasan akses; (2) Peningkatan mutu, relevansi, dan daya saing; dan (3) Peningkatan tata kelola, akuntabilitas, dan pencitraan publik. Pada aspek pemerataan pendidikan pada hakikatnya adalah setiap orang/penduduk mempunyai kesempatan yang sama untuk memperoleh pendidikan pada semua jenis dan tingkatan lembaga pendidikan, tanpa dibedakan jenis kelamin, status sosial, ekonomi, masyarakat, agama, suku, dan lokasi geografis. Sasaran aspek pemerataan adalah menciptakan keadilan dan kesejahteraan yang merata melalui pelayanan pendidikan. Pemerataan pendidikan mencakup persamaan kesempatan, akses, keadilan atau kewajaran.

Contoh kegiatan di bidang pemerataan kesempatan dan perluasan akses pendidikan adalah pemberian beasiswa untuk siswa miskin atau yang rentan putus sekolah, pelatihan guru PLB, pembenahan SLTP terbuka, pengembangan SD-SMP Satu Atap, peningkatan angka melanjutkan, pengurangan angka putus sekolah, dan sebagainya. Dengan demikian pemerataan pendidikan sebagai indikator pembangunan pendidikan menjadi permasalahan pokok, sebab dimungkinkan terjadi peningkatan angka anak tidak dan putus sekolah.

2. Menggalakkan Konsep Pendidikan Seumur Hidup

Pendidikan konsep seumur hidup merupakan pemecahan atas masalah putus sekolah. Pendidikan dalam rangka pendidikan seumur hidup menjadi 
sangat penting untuk mendewasakan warga negara dalam kehidupan demokrasi, kehidupan berbangsa dan bernegara. Sehingga perkembangan institusi politik dapat dimainkan secara jujur oleh seluruh komponen bangsa. Pendidikan adalah proses bimbingan dalam upaya pembentukan akhlak mulia dengan tidak melupakan kemajuan duniawi dan ilmu pengetahuan yang berguna untuk perseorangan dan ke-masyarakatan. ${ }^{15}$ Mengenai pengertian seumur hidup adalah perjalanan manusia seumur hidup (lifelong). ${ }^{16}$ Dengan demikian, konsep pendidikan seumur hidup yang dimaksud di sini adalah rancangan atau gagasan tentang proses pembimbingan manusia yang terus berlangsung.

Dari konsep inilah, lahir beberapa istilah yang mengacu pada termininologi pendidikan seumur hidup, yakni dalam International Dictionary of Education dikatakan bahwa pendidikan seumur tiada lain kecuali adalah pendidikan orang dewasa (adult education), pendidikan permanen (educational permanent) atau pendidikan berulang (recurrent education) ${ }^{17}$ Istilah-istilah ini, kemudian terkonsep dalam istilah life long education atau life long integrated education. Untuk itu, pendidikan formal harus diutamakan bagaimana cara belajar, menanamkan motivasi yang kuat dalam diri anak didik untuk belajar terus menerus sepanjang hayatnya.

Kebijaksanaan negara menetapkan prinsip pembangunan nasional, sebagai pembangunan manusia seutuhnya, di mana pembangunan bangsa dan watak bangsa di mulai dengan pembangunan subjek manusia. Pembangunan manusia Indonesia seutuhnya secara khusus merupakan tanggung jawab lembaga-lembaga pendidikan, yang berlangsung secara terus-menerus tanpa batas usia. Dengan demikian, asas pendidikan seumur hidup bertitik tolak atas keyakinan bahwa proses pendidikan dapat berlangsung selama manusia hidup, baik di dalam maupun di luar sekolah.

Pendidikan seumur hidup diarahkan kepada orang-orang putus sekolah yang sadar tentang diri mereka untuk belajar seumur hidup. Sebagai pelajar seumur hidup, mereka harus melihat sistem belajar baru sebagai cara yang logis untuk mengatasi problema dan terdorong untuk belajar di seluruh tingkat usia dan menerima tantangan dari perubahan. Sistem pendidikan seumur hidup bertujuan membantu perkembangan orang-orang secara sadar dan sistematik merespon untuk beradaptasi dengan lingkungan. Burhanuddin

\footnotetext{
${ }^{15}$ Bahaking Rama, Sejarah Pendidikan Islam; Pertumbuhan dan Perkembangan Hingga Masa Khulafaurrasyidin (Cet. I; Jakarta: Paradotama Wiragemilang, 2002), h. 8. Llihat juga H. Mappanganro, Implementasi Pendidikan Islam di Sekolah (Cet.I; Ujung Pandang: Yayasan Ahkam, 1996), h. 10. 2004), h. 79

${ }^{16}$ Redja Mudyahardjo, Filsafat Ilmu Pendidikan ( Bandung: Remaja Rosda Karya, 1980), h. 206

${ }^{17}$ Tery Page, et. all, International Dictionary of Education (Camridge: The MIT Press,
} Jurnal Al-Ishlah, Volume XI No. 20 Januari-Juni 2013 
Salam merumuskan pendidikan manusia seutuhnya dan seumur hidup bertujuan: pertama, Untuk mengembangkan potensi kepribadian manusia sesuai dengan kodrat dan hakikatnya, yakni seluruh aspek pembawaannya seoptimal mungkin. Kedua, Berlangsung selama manusia hidup seirama pertumbuhan kepribadian manusia yang bersifat dinamis. ${ }^{18}$

Pendapat kedua tokoh pendidikan di atas, memberikan gambaran bahwa tujuan pendidikan seumur hidup dilaksanakan sebagaimana upaya pengembangan potensi kepribadian manusia sesuai dengan kodrat penciptaannya. Makhluk berkepribadian yang memiliki potensi-potensi dan memiliki hak yang sama dalam menerima pendidikan untuk mengembangkan seluruh potensinya sepanjang hidupnya.

3. Pemaanfaatan berbagai Kegiatan Kerja bagi Putus Sekolah dan

Pengangguran

Hidup ini harus diisi dengan kegiatan yang bermanfaat. Ajaran Islam, bahkan seluruh agama tidak memberi peluang sedikit pun bagi seorang untuk menganggur di sepanjang saat yang dialaminya dalam kehidupan dunia ini. Seseorang yang telah memenuhi waktunya dengan pekerjaan, kemudian dia menyelesaikan pekerjaan tersebut, maka waktu antara selesainya pekerjaan yang pertama dan dimulainya pekerjaan. ${ }^{19}$

Jika menghadapi dua alternatif untuk melakukan satu di antara dua pekerjaan yang sama dan memiliki nilai yang sama pula, maka hendaknya dipilih pekerjaan yang memakan waktu lebih singkat. Di sisi lain, jika ada pekerjaan yang mengandung nilai tambah dan dapat diselesaikan dalam waktu yang sama dengan pekerjaan yang tidak memiliki nilai tambah, maka pilihlah pekerjaan yang memiliki nilai tambah tersebut. ${ }^{20}$ Di samping pekerjaan bermanfaat, bagi mereka yang putus sekolah bisa memanfaatkan waktu untuk tetap melakukan pendidikan secara non formal, sebab sebagaimana yang dipahami bahwa pendidikan merupakan kebutuhan mutlak yang harus dipenuhi.

Melalui pendidikan nonformal, mereka yang putus sekolah dapat hidup berkembang sejalan dengan aspirasi untuk maju, sejahtera, dan bahagia menurut konsep dan pandangan hidupnya hal ini relevan dengan kebutuhan bangsa sekarang ini yang masih dalam proses perkembangan. Hal ini berarti bahwa, setiap manusia diharapkan agar selalu berkembang sepanjang hidupnya, dan di lain pihak masyarakat dan pemerintah diharapkan agar dapat menciptakan situasi yang menunjang untuk belajar dan bagi masyarakat membuka lembaga pendidikan nonformal. Dengan adanya lembaga pendidikan

\footnotetext{
${ }^{18}$ Burhanuddin Salam, Dasar-dasar Paedagogie (Jakarta: Bumi Aksara, 1989), h. 214.

${ }^{19}$ Lihat M. Quraish Shihab, Wawasan Al-Qur'an; Tafsir Mawdhui atas Pelbagai Persoalan Umat. Cet. XV (Jakarta: Mizan, 2004), h. 224.

${ }^{20}$ Lihat M. Quraish Shihab, op. cit., h. 225-226.
} 
nonformal ini, secara tidak langsung memberi peluang kepada mereka yang putus sekolah untuk mengembangkan potensi-potensi yang dimilikinya pada jalur, jenjang, dan jenis pendidikan tertentu, namun tidak dapat dipungkiri bahwa lembaga pendidikan tersebut, belum dapat dinikmati oleh semua lapisan masyarakat.

4. Memaksimalkan peran lingkungan sosial keluarga dalam kelanjutan Pendidikan Anak

Lingkungan keluarga, utamanya orang tua merupakan pendidik utama dan pertama bagi anak-anak mereka. Corak pendidikan dalam rumah tangga secara umum tidak berpangkal tolak dari kesadaran dan pengertian yang lahir dari pengetahuan mendidik, melainkan secara kodrati suasana dan strukturnya memberikan kemungkinan alami membangun situsi atau iklim pendidikan yang berkelanjutan. Timbulnya iklim atau suasana tersebut, karena adanya interaksi yaitu hubungan pengaruh mempengaruhi secara timbal balik antara orang tua dan anak. ${ }^{21}$ Orang tua memegang peranan yang penting dan sangat berpengaruh atas pendidikan anak-anaknya. Begitu pentingnya tanggung jawab orang tua dalam memberikan pendidikan terhadap anak-anaknya, Syauqih mengatakan seperti yang dikutip oleh Khaeruddin bahwa:

Bukanlah anak yatim itu adalah seorang anak yang kedua orang tuanya telah pergi dari kesusahan hidup dan meninggalkannya dalam keadaan hina, sesungguhnya anak yatim itu adalah anak yang mendapatkan seorang ibu yang mengabaikannya atau seorang ayah yang sibuk. ${ }^{22}$

Seorang anak apabila telah memasuki usia sekolah menjadi tugas dan tangung jawab orang tua untuk menyerahkan anaknya kepada sekolah. Hal ini tidak berarti bahwa, orang tua tersebut sudah lepas dari tanggung jawab, sebab pelayanan sekolah terhadap pendidikan anak juga sangat terbatas dalam waktu tertentu serta bahan pelajaran tertentu pula, selebihnya menjadi tugas dan tanggung jawab orang tua di rumah untuk memberikan pelayanan, pengawasan, perhatian, bahkan bimbingan belajar di rumah. Faktor lain yang menjadi tanggung jawab orang tua terhadap pendidikan anak adalah menyediakan alat-alat perlengkapan belajar anak di rumah, memperhatikan lingkungan pergaulan, memberikan kesempatan kepada anak untuk menyampaiakan dan mengungkapkan masalahnya.

5. Pendidikan Gratis.

Pemerintah mengeluarkan kebijakan pendidikan gratis, hal ini tentu tidak berlaku kepada semua daerah, karena ini merupakan program pemerintah daerah sendiri dan sifatnya tidak menyeluruh artinya kebijakan ini tidak berlaku secara nasional. Kebijakan pendidikan gratis merupakan kebijakan

\footnotetext{
${ }^{21}$ Khaeruddin, Ilmu Pendidikan Islam (Cet. I; Makassar: Yayasan Pendidikan Fatiah, 2002)., h. 100

22 Ibid., h. 102.
} 
yang diprogramkan oleh pemerintah kepada daerahnya dengan tujuan memberikan pelayanan pendidikan yang menyeluruh kepada tiap jenjang masyarakat yang membutuhkan pendidikan keberadaan program sekolah gratis ini tentunya melalui pertimbangan sebelum melakukan pengambilan keputusan untuk memberlakukan program ini kepada daerah. Beberapa hal yang mendasari program pendidikan gratis, di antaranya faktor ekonomi, mutu pendidikan, tingkat kesejahteraan masyarakat dalam hal pendidikan. Pendidikan gratis tidak sepenuhnya bisa dikatakan mengenai sasaran, hal ini disebabkan oleh pemerintah yang belum sepenuhnya merealisasikan. Namun, pendidikan gratis setidaknya mampu mengurangi pengangguran yang ada dan diharapkan mampu meningkatkan mutu pendidikan.

Pembangunan bangsa Indonesia kedepan sangat tergantung pada kualitas sumber daya manusia Indonesia yang sehat fisik dan mental serta mempunyai keterampilan dan keahlian kerja, sehingga mampu membangun keluarga yang bersangkutan untuk mempunyai pekerjaan dan penghasilan yang tetap dan layak, sehingga mampu memenuhi kebutuhan hidup, kesehatan dan pendidikan anggota keluarganya.

Dalam pembangunan Nasional, kebijakan ekonomi makro yang bertumpu pada sinkronisasi kebijakan fiskal dan moneter harus mengarah pada penciptaan dan perluasan kesempatan kerja. Untuk menumbuh kembangkan usaha mikro dan usaha kecil yang mandiri perlu keberpihakan kebijakan termasuk akses, pendamping, pendanaan usaha kecil dan tingkat suku bunga kecil yang mendukung. Kebijakan Pemerintah Pusat dengan kebijakan Pemerintah Provinsi dan Pemerintah Kabupaten/Kota erupakan satu kesatuan yang saling mendukung untuk penciptaan dan perluasan kesempatan kerja.

Ketersediaan lembaga pendidikan yang merata dengan dukungan fasilitas yang memadai, kemudian ditunjang oleh suasana lingkungan sosial masyarakat yang berorientasi pada peningkatan mutu pendidikan yang berkelanjutan akan mampu mengembangkan orientasi pendidikan yang berbasis profesinalisme kerja. Putus sekolah dan pengangguran bukanlah hal yang mesti ditakuti dan menjadi "jamur-jamur" kehidupan sosial pendidikan masyarakat apabila akses pemerintah dan masyarakat senantiasa seirama dan harmonis, sejalan dengan dinamika produktivitas sumber daya alam yang tersedia. Lapangan kerja senantiasa terbuka lebar apabila masalah-masalah sosial yang melingkupi dunia pendidikan dijadikan tolok ukur dalam pengembangan konsep-konsep dan sistem pendidikan serta dijadikan pusat kajian dalam memperjuangkan hak-hak publik, utamanya dalam pemenuhan hak-hak dalam memperoleh pendidikan.

\section{KESIMPULAN}

Berdasarkan uraian yang telah dikemukakan, dapat disimpulkan:

1. Masalah putus sekolah dan pengangguran merupakan realitas sosial yang memiliki kaitan langsung dalam dunia pendidikan. Keduanya dapat 
dijadikan sebagai tolok ukur utama dalam menilai keberhasilan dinamika pendidikan secara universal.

2. Faktor-faktor terjadinya putus sekolah dewasa ini adalah faktor endogen (diri sendiri) dan faktor eksogen (lingkungan). Hal ini diakibatkan oleh kurangnya didikan sosial keagamaan, kurang pengertian orang tua tentang pendidikan keadaan ekonomi dan sosial, dan faktor budaya, lingkungan sosial dan IQ yang rendah. Sedangkan masalah pengangguran lebih dominan diakibatkan oleh faktor profesionalisme atau keterampilan pendidikan yang berorientasi pada pemenuhan dunia kerja.

3. Beberapa upaya solusi alternatif pemecahan masalah putus sekolah, antara lain: (a) pemerataan lingkungan sosial pendidikan; (b) menggalakkan konsep pendidikan seumur hidup; (c) pemaanfaatan berbagai kegiatan kerja bagi putus sekolah dan pengangguran; (d) memaksimalkan peran lingkungan sosial keluarga dalam kelanjutan pendidikan anak; (e) melaksanakan upaya kebijakan pendidikan gratis.

4. Ketersediaan lembaga pendidikan yang merata dengan dukungan fasilitas yang memadai, kemudian ditunjang oleh suasana lingkungan sosial masyarakat yang berorientasi pada peningkatan mutu pendidikan yang berkelanjutan akan mampu mengembangkan orientasi pendidikan yang berbasis profesinalisme kerja.

Wallah A'lam bi al-Shawab.

\section{DAFTAR PUSTAKA}

Ali, Moektii, Generasi Muda Islam. Cet.II; Bandung: Remaja Rosdakarya, 1998.

Departemen Pendidikan Nasional RI, Kamus Besar Besar Bahasa Indonesia. Cet.IX; Jakarta: Balai Pustaka, 1997.

Http://dimas-apriyana.blogspot.com/.html.

Http://www.menegpp.go.id/index.php?option=com,- putus sekolah menjadi masalah.

Kartono, Kartini. Patalogi Sosial 2 Kenakalan Remaja. Cet II; Jakarta: Rajawali, 1992

Khaeruddin, Ilmu Pendidikan Islam. Cet. I; Makassar: Yayasan Pendidikan Fatiah, 2002.

Mappanganro, H. Implementasi Pendidikan Islam di Sekolah. Cet.I; Ujung Pandang: Yayasan Ahkam, 1996. 
Mudyahardjo, Redja. Filsafat Ilmu Pendidikan . Bandung: Remaja Rosda Karya, 2004.

Page, Terry, et. all, International Dictionary of Education. Camridge: The MIT Press, 1980.

Purwanto, M. Ngalim. Ilmu Pendidikan Teoritis dan Praktis. Cet. XV; Bandung: Remaja Rosdakarya, 2003

Purwoko, Yudha. Memecahkan Masalah Remaja. Cet I; Bandung: Nuansa, 2001.

Rahman Getteng, H. A. Pendidikan Islam dalam Pembangunan. Ujung Pandang : Yayasan al-Ahkam, 1997.

Rama, Bahaking. Sejarah Pendidikan Islam; Pertumbuhan dan Perkembangan Hingga Masa Khulafaurrasyidin. Cet. I; Jakarta: Paradotama Wiragemilang, 2002

Salam, Burhanuddin Salam, Dasar-dasar Paedagogie. Jakarta: Bumi Aksara, 1989.

Shihab, M. Quraish Shihab, Wawasan Al-Qur'an; Tafsir Mawdhui atas Pelbagai Persoalan Umat. Cet. XV. Jakarta: Mizan, 2004.

Shohib, Moh., Pola Asuh Orang Tua. Cet. I; Jakarta: PT. Rineka Cipta, 1998

Sihombing, U. Konsep dan pengembangan pendidikan berbasis masyarakat. Dalam Fasli Jalal, \& Dedi Supriadi. "Reformasi pendidikan dalam Konteks Otonomi Daerah”. Yogyakarta: Adicitahal. 2001

Tilaar, H.A.R. Pendidikan Masyarakat Indonesia Baru. Jakarta: Gramedia. 2002

Tobing, Elwin. Pengangguran Tenaga Kerja Terdidik. Media Indonesia. 2004.

Wibawa, B.. Partisispasi masyarakat: Potret tahun kedua di era otonomi pendidikan. (Makalah). Jakarta: UNJ. 2002 